\title{
THE ANALYSIS OF GRAPHIC DESIGN PLATFORMS USED IN SOCIAL MEDIA MARKETING
}

\author{
Ksenija Mitrović (D), Anja Jakšić (D), Jelena Spajić (iD) \\ University of Novi Sad, Faculty of Technical Sciences, Department of Industrial Engineering \\ and Management, Novi Sad, Serbia
}

\begin{abstract}
Development of the internet conditioned the evolution of marketing. Nowadays, organizations have relocated their marketing activities on the internet, so digital marketing comes into focus, as the most influential branch of marketing. A progress of digital marketing activities established the appearance of different digital marketing elements, among which social media marketing becomes more prevalent. Social media marketing is an inevitable element of digital marketing strategy and nowadays business. In order to complement social media marketing activities, graphic design is used as a crucial part of a content strategy. This paper focuses on the importance of effective visual content for social media and the usage of different tools that can facilitate and improve its creation. Social media users interact with visual content. In order to achieve higher engagement, social media posts are enriched with compelling visuals. Social media have become a real field for competition in terms of creating competitive content and attracting more users' attention. The aim of this paper is to analyze the effectiveness of online graphic design tools that are used for creating visual content adapted to the requirements of communication on social networks. Given the importance of visuals in social media marketing, an abundance of tools are created with different features in order to support content design. These online platforms offer complete customization options, a wide range of different editing tools and templates and diverse functionalities. Visual content, through social media platforms, boosts user awareness of existing brands and makes it easier for users to associate with the organization. Through a relevant literature review in the field of social media marketing, the importance of visual elements and graphic design in online marketing communication is emphasized. In addition, this paper provides a comparative analysis of the most commonly used online tools and platforms that provide graphic design solutions and increase the effectiveness of online marketing campaigns.
\end{abstract}

Key words: social media marketing, visual communication, content strategy, graphic design tools

\section{INTRODUCTION}

Development of the Internet and social networks led to creating a new business model where a general presence on social media represents a competitive advantage for brands. In such conditions, social media marketing becomes an integral part of digital marketing and one of the vital tools for overall marketing strategy (Ahmad et al, 2016). Social media enables bringing together a large number of people from different backgrounds to design, modify, share and discuss Internet content (Tafesse, 2015). Being competitive on the digital market imposes generating marketing content adjusted for the audience and distributed by the right social networks. Well-designed content is a cornerstone of a brand's online presence (Gunelius, 2010), since visual content drives social media exposure and engagement as well as traffic to websites. In order to make visual communication attractive and effective, the intervention of graphic design in marketing communication is required (Abdel-Rahim and Ali, 2016).

With the purpose of combining technology with art better and facilitating the process of creation of visual content, an abundance of platforms are introduced online. Therefore, this paper analyzes the most commonly used online tools and platforms that provide graphic design solutions and increase the effectiveness of online marketing campaigns. The most relevant of them will be presented and compared. With the intention to examine the usage of these platforms, web analytics is conducted using an online platform for website traffic statistics and analytics, named SimilarWeb. After that, the most visited platforms were analyzed according to their functionalities and features in order to highlight those that are most suitable and effective for social media marketing. 


\section{SOCIAL MEDIA MARKETING}

Since the number of online users and browsing time increase, social networks are recognized as the powerful marketing channels (Chang et al, 2015). Social media represents online publishing and communication tools, sites, and destinations of Web 2.0 (Gunelius, 2010) enabling content sharing, information diffusion, and relationship building (Kim and Ko, 2012). Many forms of social media are familiar (Zarrella, 2009):

- blogs,

- microblogs,

- social networks,

- media-sharing sites,

- social bookmarking and voting sites,

- review sites,

- forums,

- virtual worlds.

Nowadays, it is the fastest way to get information. Appel et al. (2020) assert the practical aspect of social media, describing them as "a collection of software-based digital technologies-usually presented as apps and websites - that provide users with digital environments in which they can send and receive digital content or information over some type of online social network". Considering the presence of these platforms in everyday life, an opportunity to connect with the customer in a new way arose.

Social media gives marketers a voice and a way to communicate with (potential) customers (Neti, 2011). Facebook, Twitter, Instagram and other social networks became the new environment for promoting products and connecting with an audience. Social media is used as a marketing medium (Kapoor et al, 2018). In that way, many marketing objectives can be achieved. According to Ocić (2014), social media enables: fast exchange of information and interactivity, encouragement of influence of direct marketing, improving the branding process, attention direction on specific products, improving the process of loyalty and trust, conducting market research and monitoring competition, considering customer opinions and so forth (Ocić, 2014). 2020 Social Media Marketing Industry Report (Stelzner, 2020) shows the most indicated benefits of the usage of social media marketing: $86 \%$ of respondents consider increased exposure as a result of their efforts. The second major benefit is increased traffic with $78 \%$, followed by generated leads (67\%) and developed loyal fans (60\%).

The ease of finding information online gives customers more options than ever. A presence on social media is now an imperative, but thanks to the social web, brands get more exposure, making it challenging to establish adequate communication with their customers.

\section{CONTENT MARKETING}

Brands use content marketing to create and share their stories (Baltes, 2015). Content Marketing Institute defines it as "a strategic marketing approach focused on creating and distributing valuable, relevant, and consistent content to attract and retain a clearly defined audience - and, ultimately, to drive profitable customer action" (Content Marketing Institute, 2020). It focuses on providing value for the customer in the form of relevant information and ideas (Vinerean, 2017). High-quality content empowers driving the engagement on social media, and has a significant role in the social media marketing campaign (Ahmad et al, 2016).

Brands today face the challenge of creating and sharing content that builds and sustains the recognition of their posts on social media (Chauhan and Pillai, 2013). It is expected from them to provide the content that is able to answer all the customers' queries in a very attractive and creative way (Ahmad et al, 2016). According to Five Software Marketing Trends for 2020 (Gartner, 2019) customers should be guided with attractive content and encouraged for participation through social media, contests and review collection to extend brand exposure across their relevant networks. It is stated that " $91 \%$ of consumers prefer interactive or visual content, such as video, over conventional static media". Graphic design has an important role in generating what customers expect on the network. It is considered as a visual piece that leads customers through intended messages (Tresnic Media, 2020).

When reaching out to people on social media, brands need to prove they have something valuable to say. Thus, an adequate content can position them as an authoritative, contributing member of the social Web 
community (Gunelius, 2010). Social media is very visual which explains the importance of content design (Gancho et al, 2013). Marketing and graphic design together create social media spaces. With the help of graphic design messages are presented through innovative design elements that ultimately give the audience stellar visual experience. Capturing customer's attention is one of the primary factors that drive marketers to integrate graphic design into their content strategy (Abdel-Rahim and Ali, 2016). Design dictates the aesthetics and friendliness of social media networks (Gancho et al, 2013). It is used to execute visual marketing through an array of graphic aspects such as infographics, videos, mailers and animations (Abdel-Rahim and Ali, 2016).

\section{ONLINE VISUAL IDENTITY}

Communication in society today is much more visually oriented. Visual culture is replacing printed or written culture (Rodríguez Estrada and Davis, 2015), giving graphic design a greater significance. Brands try to show their visual statement of who they are. Every time customers interact with a brand, they are exposed to visual stimuli such as logos, shapes, colours, characters, styles and other elements that define the brand's image (McQuarrie and Phillips, 2008). These elements are associated with the brand and help customers to identify it.

Social networks have become an imperative of today's business, so brands need to broaden their online presence. The Internet allows greater involvement of brand experience and brand engagement in the communities through interaction, which consequently leads to brand loyalty, encouraging trust and creating greater value to consumers (Jayasingh, 2019). In the online world, it only takes four to eight seconds to impress the audience, so attractive graphics are important to this process (Gancho et al, 2013). Graphic design can influence the look, ambience, functionality and the message which a brand intends to convey (Abdel-Rahim and Ali, 2016). The aspiration is to create a look and feel that will harmonize visual communication in a way that further represents the brand to the audience.

Visual communication design transforms as people's needs change. Under the influence of digital media, it has been given new features (Zhang, 2018), resulting in a wide range of online tools that facilitate creating compelling visual content. The usage of different design features creates a point of differentiation on the market, strengthens a brand's image and improves customers' loyalty (Magrath and McCormick, 2013). Compelling visuals connect the brand with its audience. They encourage discussion and shares. Also, it is shown that visual appeal can influence the quality of interaction between a customer and online stimuli (Lee et al, 2015).

Since design facilitates the interaction between brands and customers (Gancho et al, 2013), content should be carefully created to be stimulative and interactive (Duffett, 2015). Delivering an engaging experience online will affect customers' buying behaviour (Rowley, 2004) and designing that experience is a challenge. Building a desired image and recognition is supported with adequate reaching to people. Creating distinct and powerful content on a daily basis is supported with different online platforms. They help designers in generating any type of visual content and make the process more efficient. These image-creation and editing tools enable designing custom images, graphs, charts, memes, infographics, making cohesive look across all the channels. Besides producing an appealing visual in a wide range of formats, they offer a possibility to publish and share the design easily.

\section{THE ANALYSIS OF GRAPHIC DESIGN PLATFORMS USED IN SOCIAL MEDIA MARKETING}

As the website Tweak Your Biz is one of the leading global publication and online business communities, we considered it as a relevant source for the list of most important graphic design tools for social media marketing. This web site receives over 50.000 unique views per month and publishes a large amount of articles which cover every aspect of corporate lifestyle (Tweak Your Biz, 2020).

According to Tweak Your Biz, the best online graphic design tools are (Tweak Your Biz, 2020):

1. PhotoADKing;
2. Canva;
3. Befunky;
4. Pixlr;
5. Infogram;
6. Snappa;
7. Pablo;

1. PhotoADKing;

2. Canva;

3. Befunky;

4. Pixlr;

5. Infogram

7. Pablo 

15. Gravit;
16. Venngage;
17. PhotoVisi;
18. TimelineCoverBanner;
19. Landscape;
20. IPICCY.

To verify the validity of this ranking, an online tool for website traffic statistics and analytics, named SimilarWeb was used for web analytics in order to compare and evaluate these online graphic design tools. The SimilarWeb results for website traffic are presented in a Table 1.

Table 1: SimilarWeb traffic analysis of graphic design tools used in social media marketing

\begin{tabular}{|c|c|c|c|c|c|c|c|c|c|}
\hline No. & $\begin{array}{l}\text { Graphic tool } \\
\text { name }\end{array}$ & $\begin{array}{l}\text { Total } \\
\text { visits }\end{array}$ & $\begin{array}{l}\text { Average } \\
\text { visit } \\
\text { duration }\end{array}$ & $\begin{array}{l}\text { Bounce } \\
\text { rate }\end{array}$ & $\begin{array}{c}\text { Traffic } \\
\text { from } \\
\text { Search }\end{array}$ & $\begin{array}{l}\text { Organic } \\
\text { Search }\end{array}$ & $\begin{array}{l}\text { Paid } \\
\text { Search }\end{array}$ & $\begin{array}{l}\text { Traffic } \\
\text { from } \\
\text { Social } \\
\text { Media }\end{array}$ & $\begin{array}{l}\text { Traffic } \\
\text { from } \\
\text { Direct }\end{array}$ \\
\hline 1 & PhotoADKing & $84,68 \mathrm{~K}$ & 00:08:05 & $37,18 \%$ & $68,18 \%$ & $76,08 \%$ & $23,92 \%$ & $6,11 \%$ & $24,04 \%$ \\
\hline 2 & Canva & $146,79 \mathrm{M}$ & 00:07:11 & $27,32 \%$ & $21,89 \%$ & $88,81 \%$ & $11,11 \%$ & $3,32 \%$ & $71,40 \%$ \\
\hline 3 & BeFunky & $4,71 \mathrm{M}$ & 00:04:17 & $47,38 \%$ & $54,16 \%$ & $99,98 \%$ & $0,02 \%$ & $0,58 \%$ & $44,08 \%$ \\
\hline 4 & Pixlr & $12,81 \mathrm{M}$ & 00:03:25 & $49,87 \%$ & $31,96 \%$ & $99,98 \%$ & $0,02 \%$ & $2,76 \%$ & $63,90 \%$ \\
\hline 5 & Infogram & $2,32 \mathrm{M}$ & 00:08:33 & $72,10 \%$ & $26,25 \%$ & $99,3 \%$ & $0,07 \%$ & $6,42 \%$ & $50,70 \%$ \\
\hline 6 & Snappa & $1,56 \mathrm{M}$ & $00: 03: 25$ & $58,50 \%$ & $66,91 \%$ & $99,33 \%$ & $0,67 \%$ & $3,92 \%$ & $27,47 \%$ \\
\hline 7 & Pablo & $134,91 \mathrm{~K}$ & $00: 02: 42$ & $62,44 \%$ & $17,91 \%$ & $100 \%$ & $0 \%$ & $1,89 \%$ & $71,14 \%$ \\
\hline 8 & $\begin{array}{l}\text { Quotes } \\
\text { Cover }\end{array}$ & $144,31 \mathrm{~K}$ & 00:06:15 & $44,65 \%$ & $58,21 \%$ & $99,83 \%$ & $0,17 \%$ & $1,46 \%$ & $38,56 \%$ \\
\hline 9 & Fotor & $3,13 \mathrm{M}$ & $00: 04: 25$ & $31,49 \%$ & $60,91 \%$ & $99,98 \%$ & $0,02 \%$ & $2,12 \%$ & $34,13 \%$ \\
\hline 10 & Genially & $6,38 \mathrm{M}$ & 00:08:11 & $49,70 \%$ & $31,22 \%$ & $87,21 \%$ & $12,79 \%$ & $4,85 \%$ & $51,65 \%$ \\
\hline 11 & Easel.ly & $236,51 K$ & $00: 12: 45$ & $44,27 \%$ & $28,77 \%$ & $99,61 \%$ & $0,39 \%$ & $2,96 \%$ & $58,95 \%$ \\
\hline 12 & PiZap & $795,06 K$ & 00:05:59 & $25,10 \%$ & $46,31 \%$ & $99,92 \%$ & $0,08 \%$ & $8,86 \%$ & $41,12 \%$ \\
\hline 13 & PicMonkey & $2,88 \mathrm{M}$ & $00: 22: 15$ & $26,96 \%$ & $45,51 \%$ & $76,17 \%$ & $23,28 \%$ & $3,71 \%$ & $46,29 \%$ \\
\hline 14 & Stencil & $161 \mathrm{~K}$ & 00:05:59 & $37,49 \%$ & $22,38 \%$ & $99,67 \%$ & $0,33 \%$ & $4,73 \%$ & $62,00 \%$ \\
\hline 15 & Gravit & $232,57 \mathrm{~K}$ & $00: 03: 28$ & $63,49 \%$ & $60,85 \%$ & $88,58 \%$ & $11,42 \%$ & $7,15 \%$ & $24,41 \%$ \\
\hline 16 & Venngage & $2,48 \mathrm{M}$ & 00:04:17 & $52,26 \%$ & $72,91 \%$ & $93,11 \%$ & $6,89 \%$ & $2,48 \%$ & $21,73 \%$ \\
\hline 17 & Photovisi & $230,55 \mathrm{~K}$ & 06:42:09 & $29,90 \%$ & $71,45 \%$ & $99,98 \%$ & $0,02 \%$ & $1,58 \%$ & $24,73 \%$ \\
\hline 18 & $\begin{array}{l}\text { Timeline } \\
\text { Cover Maker }\end{array}$ & $144,31 \mathrm{~K}$ & 00:06:15 & $44,65 \%$ & $58,21 \%$ & $99,83 \%$ & $0,17 \%$ & $1,46 \%$ & $38,58 \%$ \\
\hline 19 & Landscape & $2,58 \mathrm{M}$ & 00:06:21 & $59,67 \%$ & $58,59 \%$ & $98,15 \%$ & $1,85 \%$ & $1,76 \%$ & $36,17 \%$ \\
\hline 20 & Ipiccy & $998,87 \mathrm{~K}$ & $00: 02: 41$ & $21,87 \%$ & $15,91 \%$ & $100 \%$ & $0 \%$ & $2,36 \%$ & $80,38 \%$ \\
\hline
\end{tabular}

As Table 1 indicates, the most visited site in the past six months of 2020 is Canva,with total visits at $146,79 \mathrm{M}$ visits. It is followed by Pix/r with $12,81 \mathrm{M}$ visits and Genially which recorded 6,38M visits. In the previous six month, lesser visited websites are PhotoADKing which totaled 84,68K visits and it is followed by Timeline Cover Maker with 144,31K and Pablo which amounted 134,91K visits. 
The largest average visit duration has Photovisi with $6 \mathrm{~h}$ and $42 \mathrm{~min}$. Next to it, PicMonkey and Easel.ly have larger average visit duration in comparison with the rest of the tools, respectively 22 minutes 15 seconds and 12 minutes 45 seconds. The shortest average visit duration is noted in case of Ipiccy with 2 minutes 41 seconds and Pablo with 2 minutes 42 seconds.

The highest bounce rate has Infogram with $72,10 \%$, followed by Pablo with $62,44 \%$. The bounce rate represents the number of visitors on the website, which leaves the site instead of surfing on it. The high bounce rate significates that the website is not attracting enough visitors. The lowest bounce rate has Ipiccy with 21,87\%.

Mostly traffic comes from search or direct on the website. From the search the highest level of visits have Venngage (72,91\%) and Photovisi (71,45\%) and on the opposite side, the lowest level is recorded in case of Ipiccy $(15,91 \%)$ and Pablo (17,91\%). The sites with most direct traffic are Ipiccy and Canva with respectively $80,38 \%$ and $71,40 \%$. Venngage is the site with the poorest direct traffic at $21,73 \%$.

Pablo and Ipiccy has $100 \%$ organic search, followed by Photovisi, Fotor,Pix/r and BeFunky at 99,98\% organic search. The websites with the most paid search and traffic are definitely the PhotoAdKing and PicMonkey with $23,92 \%$ and $23,28 \%$.

Social media is not one of the strongest sources of traffic for these websites. The most traffic from social media platforms got PiZap with 8,86\% and the poorest traffic from social media has BeFunky at 0,58\%.

In order to get more detailed insight to the functionalities and features that are most suitable and effective for social media marketing, the second step in this research is content analysis of the most visited platforms for graphic design. Table 2 highlights the main features that these tools offer in the context of creating SMM content.

Table 2: The analysis of functionality of the 5 most visited graphic design tools used in social media marketing

\begin{tabular}{|c|c|c|c|c|c|}
\hline GD platform & \multirow{2}{*}{ Canva } & \multirow{2}{*}{ Pixlr } & \multirow{2}{*}{ Genially } & \multirow{2}{*}{ BeFunky } & \multirow{2}{*}{ Fotor } \\
\hline Functionality & & & & & \\
\hline Basic photo editing & + & + & + & + & + \\
\hline Beauty retouching & - & + & - & + & + \\
\hline Background remover & - & + & - & + & - \\
\hline Collage Maker & + & - & - & + & + \\
\hline Photo Effects & + & + & + & + & + \\
\hline Social media templates & + & - & - & + & + \\
\hline Text editing & + & + & + & + & + \\
\hline Stickers & + & - & + & - & + \\
\hline Photo frames & + & - & - & + & + \\
\hline HDR & + & + & - & + & + \\
\hline Video editing & + & - & + & - & - \\
\hline Animation & + & - & + & - & - \\
\hline Insert audio & + & - & + & - & - \\
\hline Free stock images & + & + & + & + & - \\
\hline Free version & Yes & Yes & Yes & Yes & Yes \\
\hline $\begin{array}{l}\text { Paid version and } \\
\text { pricing }\end{array}$ & $\begin{array}{c}\text { Pro } \\
\text { 9,95\$/user } \\
\text { monthly and } \\
\text { Premium } \\
\text { 30\$/user } \\
\text { monthly }\end{array}$ & $\begin{array}{c}\text { Premium } \\
4,90 \$ \text { and } \\
\text { Professional } \\
14,99 \$\end{array}$ & $\begin{array}{c}\text { Pro, Master } \\
\text { and Team } \\
\text { package } \\
\text { (respectively: } \\
7,49 \$ \\
20,82 \$ \\
79,15 \$ \\
\text { monthly) }\end{array}$ & $\begin{array}{c}6,99 \$ \\
\text { monthly/59,88\$ } \\
\text { annually }\end{array}$ & $\begin{array}{c}8,99 \$ \\
\text { monthly/39,99\$ } \\
\text { annually }\end{array}$ \\
\hline
\end{tabular}


As Table 2 indicates, different types of graphic design online platforms provide different features. For instance, for photo editing the most convenient tools are Pixlr and BeFunky, as for the removing background. All presented tools have option to design text and making special effects on the photos. Video and audio editing have only two of five tools - Canva and Genially. Templates for social media have three of five analyzed tools - Canva, Fotor and BeFunky. The all five of most visited graphic design online tools have free version, but also the paid one. The highest price for the pricing packages has Canva.

\section{CONCLUSION}

Visual communication is the present and the future of digital marketing. Digital marketing strategy cannot be successful without having quality content. This paper analyzed the most used platforms to make the communication process on social media effective and efficient. Conducted research highlighted 20 tools and used digital market intelligence platform to explore their site analytics. The results show that the parameters vary among platforms. Number of total visits proves the wide use of these websites, reaching up to $146,79 \mathrm{M}$ visits. Quick access to personal workspace anytime and everywhere is the actuator of visits. Also, the usage of these platforms is the solid foundation for communicating the ideas and saving them in one place. Some of the mentioned platforms use social media and paid search, but the data show that it is not the strongest source to attract users. Search and direct drive most traffic.

In the context of these tools' functionalities for social media marketing, we can conclude that different tools contribute to different options, and best one cannot be chosen. For advanced editing photos, the great free solutions are Pixlr and BeFunky, but for creating memorable content for social media networks, Canva and Fotor have a huge range of features that can be used for different platforms and public. Genially is a tool which is created with wide range of purposes, but with lack of some important features related with social media marketing. Observing the effectiveness of these tools in the context of creating content for SMM, according to the identified parameters, it can be concluded that Canva meets the largest number of these requirements, however for certain functionalities some of the other observed online tools are more efficient.

Since today's business moved to the online world, it is easiest to find customers on social networks. People are visual beings who spend a lot of time on social media. In order to attract them and draw their attention to the promotional content, it is necessary to create a unique design and differentiate from others. Compelling visual content is needed and marketing communications are greatly supported and empowered by graphic design platforms that are easy and simple to use. Visuals are memorable and relatable. Whether it is used to express the brand, promote a product or convey a message, visual content is the path to get in front of customers in a powerful, interactive, and meaningful way.

\section{REFERENCES}

[1] Abdel-Rahim, F., Ali, M.: "A study on impact of graphic design on marketing in sultanate of Oman", Shanlax International Journal of Arts, Science \& Humanities 4(2), 65-76, 2016.

[2] Ahmad, N. S., Musa, R., Harris, M., Harun, M.: "The Impact of Social Media Content Marketing (SMCM) towards Brand Health", Procedia Economics and Finance 37, 331-336, 2016. doi: 10.1016/S2212-5671(16)30133-2.

[3] Appel, G., Grewal, L., Hadi, R., Stephen, A. T.: "The future of social media marketing", Journal of the Academy of Marketing Science 48, 79-95, 2020. doi: 10.1007/s11747-019-00695-1.

[4] Baltes, L. P.: "Content marketing - the fundamental tool of digital marketing", Bulletin of the Transilvania University of Brasov, Series V: Economic Sciences 8(57), 111-118, 2015.

[5] Chang, Y-T., Yu, H., Wu, H-P.: "Persuasive messages, popularity cohesion, and message diffusion insocial media marketing", Journal of Business Research 68, 777-782, 2015. doi: 10.1016/j.jbusres.2014.11.027.

[6] Chauhan, K., Pillai, A.: "Role of Content Strategy in Social Media Brand Communities: A Case of Higher Education Institutes in India", Journal of Product and Brand Management 22(1), 40-51, 2013. doi: 10.1108/10610421311298687.

[7] Content Marketing Institute: "What is Content Marketing", URL: https://contentmarketinginstitute.com/what-is-content-marketing/ (last request: 2000-08-26).

[8] Duffett, R. G.: "Facebook advertising's influence on intention-to-purchase and purchase amongst millennials", Internet Research 25(4), 498-526, 2015. doi: 10.1108/IntR-01-2014-0020. 
[9] Gancho, S., Cooper, R., Evans, M.: "The impact of Design in social media today", Proceedings of 2nd Cambridge Academic Design Management Conference 2013, (CADMC: Cambridge, UK, 2013), pages 673-686.

[10] Gartner: "Five Software Marketing Trends for 2020", URL: https://www.gartner.com/en/digitalmarkets/insights/five-software-marketing-trends-for-2020 (last request: 2020-08-26).

[11] Gunelius, S.: "30-Minutes Social Media Marketing", (McGraw-Hill Professional, 2010.), page 10.

[12] Jayasingh, S.: "Consumer brand engagement in social networking sites and its effect on brand loyalty", Cogent Business and Management 6(1), 2019. doi: 10.1080/23311975.2019.1698793.

[13] Kapoor, K.K., Tamilmani, K., Rana, N.P., Patil, P., Dwivedi, Y.K., Nerur S.: "Advances in social media research: past, present and future", Information Systems Frontiers 20(3), 531-558, 2018. doi: 10.1007/s10796-017-9810-y.

[14] Kim, A.J., Ko, E.: "Do social media marketing activities enhance customer equity? An empirical study of luxury fashion brands", Journal of Business Research 65(10), 1480-1486, 2012. doi: 10.1016/j.jbusres.2011.10.014.

[15] Lee, J., Ahn, J.-H., Park, B.: "The effect of repetition in Internet banner ads and the moderating role of animation", Computers in Human Behavior 46, 202-209, 2015. doi: 10.1016/j.chb.2015.01.008.

[16] Magrath, V., McCormick, H.: "Branding design elements of mobile fashion retail apps", Journal of Fashion Marketing and Management 17(1), 98-114, 2013. doi: 10.1108/13612021311305164.

[17] McQuarrie, E. F., Phillips, B. J.: "It's not your father's magazine ad: Magnitude and direction of recent changes in advertising style", Journal of Advertising 37, 95-106, 2008.

[18] Neti, S.: "Social media and its role in marketing", International Journal of Enterprise Computing and Business Systems 1 (2), 1-15, 2011.

[19] Ocić, Č.: "Moguće strategije razvoja Srbije”, (SANU, Beograd, 2014.).

[20] Rodríguez Estrada, F.C., Davis, L.S.: "Improving Visual Communication of Science Through the Incorporation of Graphic Design Theories and Practices Into Science Communication", Science Communication 37(1), 2015. doi: 10.1177/1075547014562914.

[21] Rowley, J.: "Online branding", Online Information Review 28 (2), 131-138, 2004. doi: 10.1108/14684520410531637.

[22] Stelzner, M.: "2020 Social Media Marketing Industry Report”, Social Media Examiner, URL: https://www.socialmediaexaminer.com/social-media-marketing-industry-report-2020/ (last request: 2020-08-26).

[23] Tafesse, W.: "Content Strategies and Audience Response on Facebook Brand Pages", Marketing Intelligence \& Planning 33 (6), 927-943, 2015. doi: 10.1108/MIP-07-2014-0135.

[24] Tresnic Media: "3 Ways Graphic Design is Used in Content Marketing", URL: https://tresnicmedia.com/3-ways-graphic-design-is-used-in-content-marketing/ (last request: 202008-26).

[25] Tweak Your Biz: "Best Graphic Design Tools For Social Media Marketing", URL: https://tweakyourbiz.com/marketing/graphic-design-tools-smm (last request: 2020-09-01).

[26] Vinerean, S.: "Content Marketing Strategy. Definitions, Objectives and Tactics", Expert Journal of Marketing 5 (2), 92-98, 2017.

[27] Zarrella, D.: "The Social Media Marketing Book", 1sted. (O'Reilly Media, Inc., Sebastopol, 2009.), page 3.

[28] Zhang, L.: "Design and Research on Visual Communication under the Influence of Digital Media", Proceedings of the 6th International Conference on Social Science, Education and Humanities Research (SSEHR: Jinan, China, 2017), pages 257-260. doi: 10.2991/ssehr-17.2018.60.

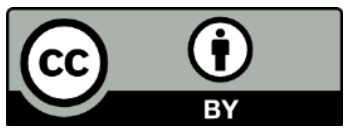

(C) 2020 Authors. Published by the University of Novi Sad, Faculty of Technical Sciences, Department of Graphic Engineering and Design. This article is an open access article distributed under the terms and conditions of the Creative Commons Attribution license 3.0 Serbia (http://creativecommons.org/licenses/by/3.0/rs/). 